\title{
Influence of slice thickness on MR flow quantification in turbulent jets
}

\author{
Matthias A Dieringer ${ }^{1 *}$, Andreas Greiser ${ }^{2}$, Jeanette Schulz-Menger ${ }^{1}$ \\ From 2011 SCMR/Euro CMR Joint Scientific Sessions \\ Nice, France. 3-6 February 2011
}

\section{Introduction}

Magnetic Resonance (MR) based flow quantification is of high interest in several cardiac diseases, e.g. valvular stenosis. However, accurate results remain challenging in several conditions. Recently, some contributors could be defined including echo time [1] (TE) and background phase errors [2]. We investigated the influence of slice thickness on flow quantification in turbulent flow.

\section{Methods}

A flow phantom was developed, which disposes of an adjustable pump and a model similar to the shape of a human aorta (Figure 1). To imitate an aortic stenosis, a Perspex plate with a borehole $\left(\mathrm{D}=11.5 \mathrm{~mm} ; \mathrm{A} \approx 1 \mathrm{~cm}^{2}\right)$ was introduced. Retrospectively gated phase contrast cine imaging (in-plane resolution $1.8 \times 1.3 \mathrm{~mm}$ ) was applied to obtain flow data from an Avanto 1.5T MR system (Siemens Healthcare Sector, Erlangen, Germany). Tested sequence settings were $a$ ) RF pulse length $=1000$ us, maximum flow encoding gradient strength $=10 \mathrm{mT} / \mathrm{m}$, $\mathrm{TE}=3.1 \mathrm{~ms} ; b) \mathrm{RF}$ pulse length $=400 \mathrm{us}$, maximum flow encoding gradient strength $=20 \mathrm{mT} / \mathrm{m}, \mathrm{TE}=2.2 \mathrm{~ms} ; c$ ) RF pulse length $=400 \mathrm{us}$, maximum flow encoding gradient strength $=20 \mathrm{mT} / \mathrm{m}, \mathrm{TE}=3.1 \mathrm{~ms}$. Tested slice thicknesses ranged from $4.5 \mathrm{~mm}$ to $10 \mathrm{~mm}$. Steady but turbulent flow $(300 \mathrm{ml} / \mathrm{s})$ was measured at $2.5 \mathrm{~cm}$ behind the stenosis (Figure 1b) with 20 calculated cardiac phases (yielding 20 flow values). Flow quantification was done using CMR42 (Circle CVi, Calgary, Canada). Average flow deviation and its standard deviation were calculated.

\section{Results}

Figure 2 shows the measured flow deviations for the tested settings $(\mathrm{a}-\mathrm{c})$ over the different slice thicknesses.

The maximum flow deviation was measured in case of an RF pulse of 1000us duration and a maximum flow encoding gradient strength of $20 \mathrm{mT} / \mathrm{m}$. Increasing $\mathrm{TE}$ did not show additional flow errors. Measurements with slice thicknesses below $6 \mathrm{~mm}$ were found to be higher than with slice thicknesses above.
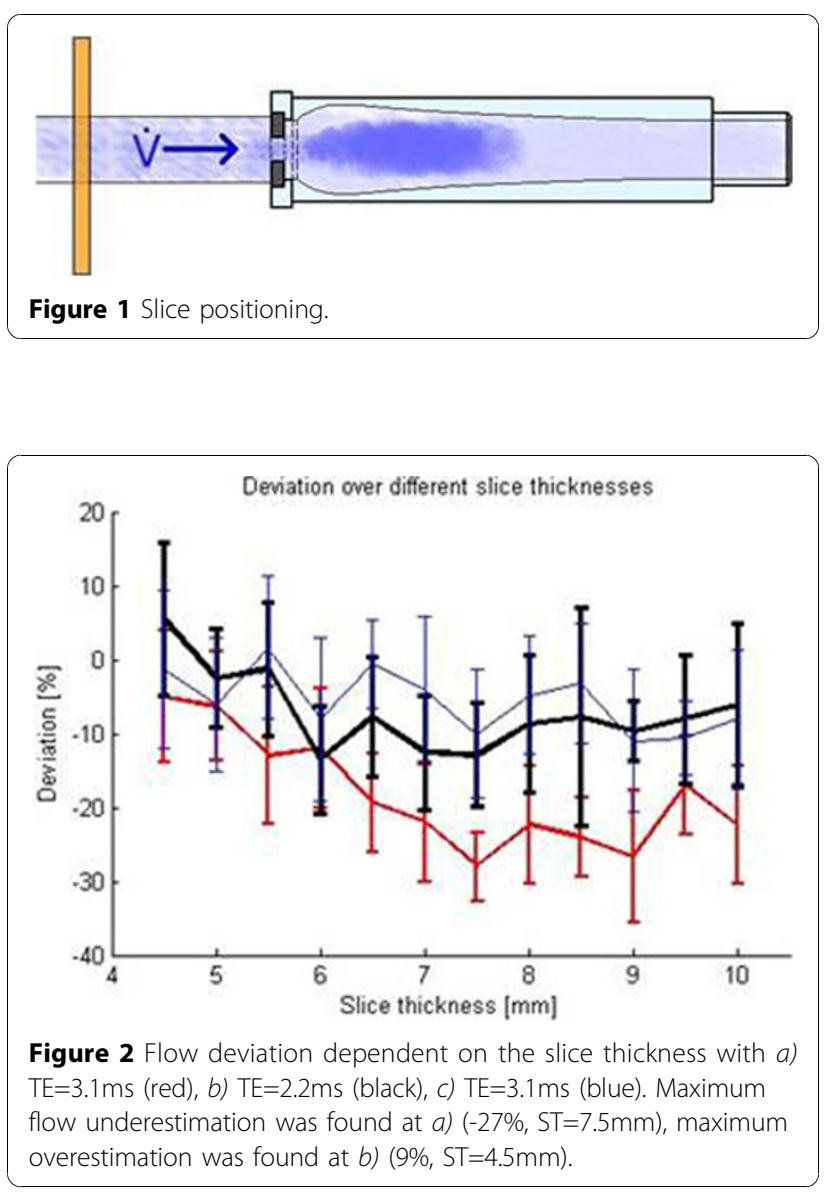


\section{Conclusion}

Our results show that slice thickness influences flow quantification in the presence of turbulent flow in certain sequence configurations. Decreasing the time of flow encoding by increasing the flow encoding gradient strength seems sufficient to mitigate flow errors for all slice thicknesses. Further investigations have to be conducted to explain the impact of the slice thickness on flow quantification in-vivo.

\section{Author details}

${ }^{1}$ Experimental and Clinical Research Center (ECRC), Charite' - University Medicine Campus Berlin Buch, Berlin, Germany. ${ }^{2}$ Siemens Healthcare Sector, Erlangen, Germany.

Published: 2 February 2011

\section{References}

1. O'Brien K, et al: JMagnReson/maging 2008, 28(1):210-218.

2. Gatehouse PD, et al: JCardiovascMagnReson 2010, 12(5).

doi:10.1186/1532-429X-13-S1-P363

Cite this article as: Dieringer et al.: Influence of slice thickness on MR flow quantification in turbulent jets. Journal of Cardiovascular Magnetic Resonance 2011 13(Suppl 1):P363.

Submit your next manuscript to BioMed Central and take full advantage of:

- Convenient online submission

- Thorough peer review

- No space constraints or color figure charges

- Immediate publication on acceptance

- Inclusion in PubMed, CAS, Scopus and Google Scholar

- Research which is freely available for redistribution

Submit your manuscript at www.biomedcentral.com/submit
C Biomed Central 